Федянович Д. Л., канд. військ. наук, ст. наук. співроб. ${ }^{1}$

$(0000-0002-9896-8655)$

Возняк С. М., канд. техн. наук, ст. наук. співроб. ${ }^{1}$

$(0000-0002-9015-813 \mathrm{X})$

Рудніцький I. А., канд. техн. наук, ст. наук. співроб. ${ }^{2}$

(0000-0002-6304-3863)

Фучко А. Й. ${ }^{1}$

(0000-0002-8941-2217)

1 - Центр воєнно-стратегічних досліджень Національного університету оборони України імені Івана Черняховського, Київ;

2 - Навчально-науковий центр підготовки офіцерів для багатонаціональних штабів Національного університету оборони України імені Івана Черняховського, Київ

\title{
Аналіз підтримки, що надається протиборчим сторонам у сучасних воєнних конфліктах та їі вплив на можливість проведення операцій 3 підтримання миру та безпеки
}

Резюме. Проведено аналіз підтримки, яка може бути надана ззовні протиборчим сторонам у сучасних воєнних конфліктах. Визначено основні категорії (види) зовнішньої підтримки сторін у воєнному конфлікті. Визначено можливості проведення операції за принципами Статуту ООН для врегулювання конфлікту на сході України. Сформульовано основні вимоги до міжнародної багатопрофільної (багатокомпонентної) та інтегрованої миротворчої місії.

Ключові слова: воєнний конфлікт; зовнішня підтримка у воєнному конфлікті; міжнародна багатопрофільна інтегрована миротворча місія; сучасний воєнний конфлікт.

Постановка проблеми. За даними Стокгольмського міжнародного інституту дослідження миру сучасні воєнні конфлікти, наприклад, такі як український та сирійський демонструють, що вони практично вже не бувають внутрішньою справою окремої держави. На сьогодні $€$ загальновизнаним фактом, що більшість воєнних конфліктів так або інакше підтримуються зовні. Зовнішня підтримка може бути визначена як односторонне втручання третьої сторони (сторін) - країни або групи країн - на стороні опозиційного руху, або уряду країни на території якої є конфлікт [1].

За думкою експертів така підтримка може виявлятися у прямій участі у конфлікті військовослужбовців та співробітників органів безпеки або надаватися у скритих формах: надання розвідувальної інформації; матеріально-технічна підтримка; здійснення підготовки формувань як військових, так i створених поза законом; підривна діяльність в інтересах однієї зі сторін; формування рухів опору та дії на дискредитацію військовополітичного керівництва країни на території якої виник конфлікт тощо. Це суттєво ускладнює посередництво або миротворчу діяльність оскільки метою таких дій $\epsilon$ припинення бойових дій, а не допомога одній зі сторін у досягненні перемоги. За даними [1] дві третини внутрішніх воєнних конфліктів, які відбулися з 1975 року характеризувалися наявністю підтримки з боку інших країн.
Наявність зовнішньої підтримки сторін у сучасному воєнному конфлікті здійснює суттєвий вплив на зміст та можливість проведення миротворчих операцій, які за метою проведення мають бути: інструментом сприяння реалізації вже чинних мирних угод; підтримувати мирний процес; сприяти зусиллям з розбудови миру або недопущення ескалації конфлікту.

Аналіз останніх досліджень i публікацій. Питання щодо розвитку сучасних тенденцій та поглядів на проведення міжнародних операцій 3 підтримання миру i безпеки неодноразово висвітлювалися як у вітчизняних, так i у зарубіжних наукових працях і публікаціях [2-6]. Разом 3 цим питанням аналізу та оцінювання впливу характеру та видів зовнішньої підтримки сторін конфлікту на можливість i зміст проведення цих операцій приділяється недостатньо уваги. Це обумовлює необхідність проведення більш глибокого аналізу тенденцій щодо надання підтримки сторонам конфлікту зовні, їх видів та впливу на можливість проведення операцій 3 підтримання миру і безпеки та їх змісту.

Мета статті - аналіз підтримки, яка надається протиборчим сторонам у сучасних воєнних конфліктах та їі впливу на можливість проведення операцій 3 підтримання миру та безпеки за принципами Статуту $\mathrm{OOH}$.

Виклад основного матеріалу. Визначення наявності воєнного конфлікту в рамках міжнародного права різниться залежно 
від того, чи має місце збройне насильство між двома або кількома державами (міждержавний конфлікт), між державою і однією чи кількома організованими недержавними збройними угрупованнями (не міжнародний, або внутрішній конфлікт) [1]. Статистичні дані щодо кількості воєнних конфліктів, що відбуваються на сьогодні (у 2007 - 2013 рр. у середньому 35 конфліктів на рік, у $2014-$ 2016 рр. - 47 конфліктів) показують, що більшість 3 них $є$ конфліктами всередині держав. За оцінками Стокгольмського міжнародного інституту дослідження миру “... внутрішні збройні конфлікти часто мають суттєвий міжнародний вимір i можуть поширюватися на суміжні держави. Тому багато внутрішніх збройних конфліктів “інтернаціоналізувалася": в них беруть участь війська, збройні угруповання чи спостерігається якась інша форма військового втручання (наприклад, поставки озброєнь та підготовка військ) інших держав (збройних угруповань або приватних суб'єктів сусідніх держав) на боці однієї або кількох воюючих сторін”. У 2016 році третину 349 конфліктів було класифіковано як інтернаціоналізовані. Загальновідомо, що характер та особливості збройних конфліктів визначають зміст та способи проведення міжнародних операцій 3 підтримання миру і безпеки на врегулювання яких вони спрямовані. Сучасні воєнні конфлікти стають дедалі складнішими, що “становить серйозну проблему для їх концептуально-правової класифікації, а також розуміння, як розв'язувати конфлікти та запобігати їм" [1].

Інтернаціоналізація сучасних воєнних конфліктів, на наш погляд, обумовлена наявністю підтримки сторін, що беруть у них участь. 11 червня 2014 року у Раді Безпеки ООН було проведене засідання, на якому були обговорені нові тенденції у миротворчій діяльності цієї організації. На думку Генерального секретаря ООН сучасні миротворчі операції все частіше проводяться в умовах (обстановці) коли: перше - "нема миру, який потрібно охороняти”, або “політичного процесу, який потребує підтримки"; друге - нема чіткого розуміння хто $є$ сторонами конфлікту; третє миротворці стикаються 3 асиметричними та нетрадиційними загрозами [7].

Саме перша та третя умови (обстановка) у багатьох випадках формується наявністю зовнішньої підтримки сторін конфлікту. Загальновідомо, що підтримка зовні охоплюється 10 основними категоріями (видами), які наведено на рис. 1.

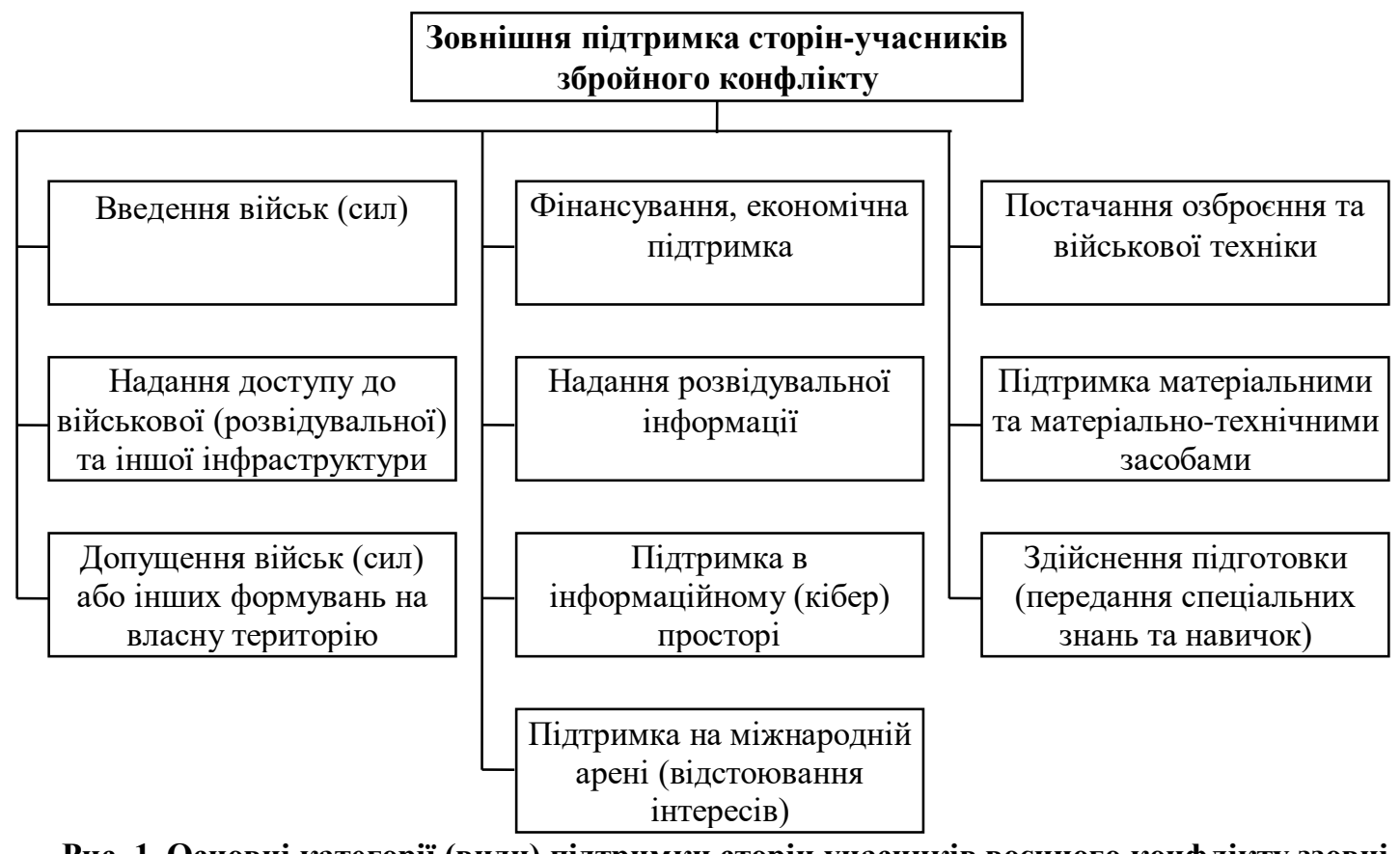

Рис. 1. Основні категорії (види) підтримки сторін-учасників воснного конфлікту ззовні (складено за матеріалами $[1,7])$

У різних воєнних конфліктах, де здійснювалася така підтримка спостерігалася різна комбінація наведених на рис. 1 видів (категорій). До цих видів підтримки зовні віднесені тільки ті, що надаються відкрито або приховано іншими країнами та не враховують можливу підтримку з боку інших акторів, які спроможні іiі надавати, наприклад, регіональні організаціi, повстанські угруповання, громадські організації та приватні військові та невійськові компанії. 
Історичний досвід показав, що сторони конфлікту зазвичай отримували різні види підтримки, деякі 3 них були схожими за видами (табл. 1). Як видно 3 табл. 1 різниця полягала лише в кількості видів підтримки, яка надавалася одночасно або послідовно, обсягах (масштабах) окремих видів підтримки, кількості учасників, що надавали підтримку та легітимності цієї підтримки. Іноді підтримка зовні здійснюється приховано, наприклад, постачання озброєння та найманців у конфлікті на сході України. Надання такої підтримки важко доказати, але вона суттєво ускладнює здійснення мирних процесів (домовленостей) для врегулювання воєнного конфлікту.

Таблиця 1

Приклади надання підтримки, що надавалася протиборчим сторонам у воснних конфліктах

\begin{tabular}{|c|c|c|c|}
\hline $\begin{array}{c}\text { Країна, на } \\
\text { території якої } \\
\text { був конфлікт }\end{array}$ & $\begin{array}{c}\text { Країна (країни), } \\
\text { які надавали } \\
\text { підтримку }\end{array}$ & $\begin{array}{c}\text { Сторона, якій } \\
\text { надавалася } \\
\text { підтримка } \\
\end{array}$ & Вид підтримки, що був наданий \\
\hline \multirow{2}{*}{$\begin{array}{c}\text { Іспанія } \\
(1936-1939 \text { рp.) }\end{array}$} & Німеччина, Італія & $\begin{array}{c}\text { Націоналістичні } \\
\text { угруповання }\end{array}$ & $\begin{array}{l}\text { Повітряні нальоти, постачання озброєння та } \\
\text { техніки }\end{array}$ \\
\hline & Радянський союз & Уряд & $\begin{array}{l}\text { Добровольці, військові } \\
\text { озброхнівці, постачання } \\
\end{array}$ \\
\hline \multirow{2}{*}{$\begin{array}{c}\text { Греція } \\
(1946-1949 \text { рр.) }\end{array}$} & $\begin{array}{l}\text { Албанія, Болгарія, } \\
\text { Югославія }\end{array}$ & Опозиція & $\begin{array}{lclr}\text { Підтримка } & \text { матеріальними } & \text { та } & \text { матеріально- } \\
\text { технічними } & \text { засобами, } & \text { підтримка } & \text { на } \\
\text { міжнародній арені } & & \\
\end{array}$ \\
\hline & $\begin{array}{l}\text { Великобританія, } \\
\text { США }\end{array}$ & Уряд & $\begin{array}{lccr}\text { Підтримка } & \text { матеріальними } & \text { та матеріально- } \\
\text { технічними } & \text { засобами, } & \text { підтримка } & \text { на } \\
\text { міжнародній арені } & & \\
\end{array}$ \\
\hline \multirow{2}{*}{$\begin{array}{c}\text { Ліван } \\
(1975-1990 \text { рр.) }\end{array}$} & Ізраїль & Опозиція & $\begin{array}{l}\text { Надання розвідувальної інформації, } \\
\text { фінансування, економічна підтримка, підтримка } \\
\text { матеріальними та матеріально-технічними } \\
\text { засобами, підтримка на міжнародній арені, } \\
\text { постачання озброєння, дії авіації }\end{array}$ \\
\hline & Сирія & Уряд & $\begin{array}{l}\text { Надання розвідувальної } \\
\text { фінансування, економічна підтримка, підтримка } \\
\text { матеріальними та матеріально-технічними } \\
\text { засобами, підтримка на міжнародній арені, } \\
\text { постачання озброєння }\end{array}$ \\
\hline $\begin{array}{c}\text { Сальвадор } \\
(1980-1992 \text { рр. })\end{array}$ & США & Уряд & $\begin{array}{l}\text { Надання військової та економічної допомоги у } \\
\text { боротьбі з повстанцями }\end{array}$ \\
\hline \multirow{2}{*}{$\begin{array}{c}\text { Афганістан } \\
(1980-1989 \text { рр.) }\end{array}$} & $\mathrm{CPCP}$ & Уряд & $\begin{array}{l}\text { Введення військ, постачання озброєння, } \\
\text { здійснення підготовки (передання спеціальних } \\
\text { знань та навичок), надання розвідувальноі } \\
\text { iнформації, матеріально-технічна підтримка, } \\
\text { інформаційна підтримка }\end{array}$ \\
\hline & $\begin{array}{l}\text { США, Пакистан та } \\
\text { інші країни }\end{array}$ & Опозиція & $\begin{array}{l}\text { Постачання озброєння, здійснення підготовки } \\
\text { (передання спеціальних знань та навичок), } \\
\text { надання } \\
\begin{array}{l}\text { матеріально-технічна підтримка, інформаційна } \\
\text { підтримка }\end{array}\end{array}$ \\
\hline \multirow{2}{*}{$\begin{array}{l}\text { Сьсрра-Леоне } \\
(1991-2002 \text { рp.) }\end{array}$} & Лівія & $\begin{array}{l}\text { Революційний } \\
\text { фронт }\end{array}$ & Підготовка на власній території \\
\hline & Ліберія & $\begin{array}{c}\text { Революційний } \\
\text { фронт }\end{array}$ & Матеріальна підтримка \\
\hline $\begin{array}{c}\text { Чад } \\
(2005-2010 \text { рр.) }\end{array}$ & Франція & Уряд & $\begin{array}{l}\text { Матеріально-технічна підтримка, надання } \\
\text { розвідувальної інформації проти повстанців }\end{array}$ \\
\hline $\begin{array}{l}\text { Лівія } \\
\text { (2011 p) }\end{array}$ & $\begin{array}{c}\text { Катар } \\
\text { (понад } 11 \text { країн) }\end{array}$ & Опозиція & $\begin{array}{lccc}\text { Постачання } & \text { зброї, } & \text { військова } & \text { підготовка } \\
\begin{array}{l}\text { повстанців, } \\
\text { призначення }\end{array} & & & \\
\end{array}$ \\
\hline \multirow{2}{*}{$\begin{array}{c}\text { Україна } \\
(2014-\text { по т.ч.) }\end{array}$} & США, країни НАТО & Уряд & $\begin{array}{l}\text { Матеріально-технічна підтримка, постачання } \\
\text { озброєння, інформаційна підтримка, підтримка } \\
\text { на міжнародній арені, здійснення підготовки } \\
\text { (передання спеціальних знань та навичок), } \\
\text { надання розвідувальної інформації }\end{array}$ \\
\hline & РФ & $\begin{array}{c}\text { Збройні } \\
\text { формування РФ та } \\
\text { iї найманці }\end{array}$ & $\begin{array}{l}\text { Введення військ, матеріально-технічна } \\
\text { підтримка, постачання озброєння та техніки, } \\
\text { інформаційна підтримка, підтримка на } \\
\text { міжнародній арені, здійснення підготовки } \\
\text { (передання спеціальних знань та навичок), } \\
\text { надання розвідувальної інформації }\end{array}$ \\
\hline
\end{tabular}


Умовно підтримку зовні можна поділити на дві категорії. Перша категорія - це підтримка, що надається зовні уряду країни на території якої розв'язаний воєнний конфлікт. Друга категорія підтримка, яка надається руху опору (незаконним збройним формуванням). Останнім часом спостерігається зменшення частки другої категорії. За даними, що отримані в рамках Упсальської програми даних про конфлікти спостерігається “стратегічний зсув” у бік підтримки зовні країнам, на території яких розв'язаний воєнний конфлікт [7]. Фахівці пояснюють таку тенденцію створенням міжнародної обстановки після 11 вересня 2001 року, коли повстанські угруповання у більшості випадків ототожнювали 3 терористичними організаціями. Збереження країнами міжнародної репутації обумовлює надання пріоритету підтримки іншим країнам у боротьбі з тероризмом [1].

Рішення про надання підтримки тієї або іншої сторони конфлікту, як правило приймаються 3 урахуванням багатьох факторів, більшість з яких, за даними [1], обумовлені характером попередніх відносин між країною, де розв'язаний збройний конфлікт та країною, що прийняла рішення про підтримку однісї із сторін конфлікту (уряду чи опозиції). Близькість до зони конфлікту також суттєво полегшує сусіднім країнам надавати підтримку у вигляді здійснення підготовки, постачання матеріально-технічних засобів, озброєння через кордон. На цім за такою підтримкою можуть стояти стратегічні цілі, зміст яких далекий від того, щоб сприяти врегулюванню конфлікту (наприклад, бажання ослабити іншу (сусідню) країну, посилити власний регіональний вплив, заволодіти природними ресурсами іншої країни тощо).

Підтримка ззовні є також фактором, що впливає на тривалість та інтенсивність сучасних воєнних конфліктів, як правило, у сторону їх збільшення [1]. До того ж суттєво зменшується ймовірність, що сторони конфлікту можуть дійти згоди шляхом переговорів. Дослідження, що проведені в рамках Упсальської програми даних про конфлікти показали, що воєнні конфлікти, у яких підтримку отримують обидві сторони, мають більшу тривалість. Це пояснюється тим, що в цьому випадку створюється рівновага сил, за якій жодна зі сторін не може успішно завершити конфлікт (ресурсів вистачає, є можливість переозброюватися, підготовка сил триває). Основна роль військових засобів у конфлікті зводиться до нейтралізації протилежної сторони, що намагається в односторонньому порядку військовим шляхом домогтися перемоги [8]

Отже, обрання воєнно-політичним керівництвом держави доцільної стратегії врегулювання конфлікту неможливе без урахування поведінки протилежної сторони конфлікту та характеру допомоги, що ій надається. Така допомога може надаватися одночасно у багатьох сферах вже існуючого протиборства - політична підтримка, економічна та фінансова підтримка, постачання озброєння та техніки, навчання та ін.

Досвід врегулювання конфлікту на сході України показав, що підтримка, що надається 3 боку РФ має комплексний характер i посилюється, або зменшується у сферах, які відповідають загальній стратегії формування певного середовища впливу на воєннополітичне керівництво України. Такі комбінації як правило включають не тільки економічні та політичні заходи, а й військові. Прикладом можуть бути зменшення обстрілів позицій українських військ перед прийняттям важливих рішень світової спільноти щодо продовження або припинення санкцій проти Росії, збільшення або зменшення інтенсивності бойових дій на окремих ділянках напередодні проведення важливих політичних заходів тощо. До того ж найбільш важливі заходи 3 демілітаризації тимчасово окупованих територій не проводяться, нормалізації роботи українських теле- та радіоканалів не спостерігається. Відсутні дії, що спрямовані на відновлення контролю кордону з РФ силами Державної прикордонної служби України.

Нині на територіях, що непідконтрольні уряду України відсутні будь-які альтернативні рухи, громадські організації або партії, діяльність яких може впливати на думку населення, що знаходиться на цих територіях. За оцінками фахівців більшість населення не підтримує позицію української влади та не бачить себе у складі суверенної держави Україна (отримання паспортів РФ найбільша показова інформаційна акція). I це є основною загрозою не тільки для процесу врегулювання конфлікту, а й фактором, який може стати визначальним для початку широкомасштабної агресії проти України.

Отже, на наш погляд, важливе значення мають підходи до проведення міжнародної операції з підтримання миру i безпеки, які 
пропонуються на сьогодні для врегулювання конфліктів. Загалом проглядається відсутність неупередженості окремих держав під час визначення формата міжнародних операцій 3 підтримання миру i безпеки. Наприклад, у 2017 році РФ розповсюдила проєкт резолюції Ради безпеки ООН, у якому пропонувалася миротворча операція на сході України, але РБ не підтримала цю ініціативу. Не отримав підтримки 3 боку РБ ООН i $\mathrm{CC}$ i запит української сторони на проведення операції по відновленню українського контролю над російсько-українським кордоном. Однією 3 причин стала швидка ескалація бойових дій i порушення режиму припинення вогню (ОБСЄ зафіксувала майже 400 тис. порушень припинення вогню впродовж 2017 року та 4 тис. випадків розгортання заборонених озброєнь 3 порушенням узгоджених ліній відведення) [1]. Ескалація конфлікту, на нашу думку, була невипадковою. П̈ї метою було створення таких умов у зоні конфлікту, які б гарантовано унеможливили реалізацію ініціативи української сторони щодо проведення операції 3 відновлення контролю за власним кордоном. За даними [7] відновлення контролю за державним кордоном означав би повний крах незаконних формувань, створених, підпорядкованих, керованих та фінансованих РФ. Ці формування за умови політичної підтримки РФ, $з$ одного боку, і України - 3 іншого, фактично мають на увазі під потенційним миротворчим зовнішнім втручанням різні регіони операцій: в одному випадку - це поділ по лінії бойового зіткнення в глибині української території, в іншому контроль українсько-російського кордону.

Така кардинальна різниця у підходах до врегулювання конфлікту є важливим фактором, який унеможливлює досягнення такого стану, за якого врегулювання воєнного конфлікту за допомогою цииільних засобів можливе за наявності компромісного типу відносин між ворогуючими сторонами. Як наслідок, у сторін конфлікту зростає невпевненість щодо доцільності йти на певні компроміси 3 іншою стороною для досягнення миру. Надання особливого статусу територіям Донбасу це лише затягування часу. А проведення демократичних виборів за українським законодавством ускладнюється значною мілітаризацією цих територій. Проведення операції Об'єднаних сил не може повністю вирішити проблеми врегулювання конфлікту. Операція $є$ лише інструментом запобігання розповсюдження збройного протистояння та механізмом здійснення контролю на кордоні 3 окремими районами Донецької та Луганської областей, що $є$ непідконтрольними уряду України.

Як випливає 3 результатів досліджень [9, 10], операції в рамках VI та VII глав Статуту ОOH також не можуть бути реалізованими для припинення конфлікту на сході України. Так, проведення операції за принципами глави VI Cmamymy $\mathrm{OOH}$ “операиї з підтримання миру” (peace-keeping) можливе у разі виконання низки умов: якщо офіційна влада України направить в ООН документовану згоду на проведення операції, якщо на цім керівництво незаконних формувань, створених, підпорядкованих, керованих і фінансованих РФ також висловить згоду на втручання з боку світової спільноти в особі ООН, якщо одночасно РФ, як постійний член РБ ООН, не накладе вето на план такої операції (у разі якщо питання буде винесено на розгляд РБ ООН), або якщо операція буде в обхід РБ ООН делегована регіональним організаціям (наприклад, НАТО або ОБСС) 3 посиланням на наявність документованої згоди конфліктуючих сторін.

Проведення ж “політичної місії ООН" 3 елементами примусових дій за принципами cm. 42 i cm. 43 глави VII Сmamymy ООН (Операції по силовому встановленню миру (peace enforcement) можливо лише в разі наявності відповідного мандату РБ ООН - що можливо лише за згоди РФ та інших постійних (а також більшості непостійних) членів РБ ООН, проте не потребує згоди так званих “ЛНР"/"ДНР" і навіть згоди України. Прикладами подібних силових операцій $\mathrm{OOH}$ є операції в Боснії, Косово, Афганістані, Іраку, Лівії - усі вони проводилися за рішенням РБООН всупереч волі влади держав, на території яких відбувався конфлікт, i включали істотний силовий компонент i примусові дії. Однак в сучасних умовах існування режиму припинення вогню прийняття мандата $\mathrm{OOH}$ на силову операцію практично неможливо та є недоцільним.

У найближчій перспективі актуальним залишається повернення до ініціативи щзодо розгортання міжнародної миротворчої місї. Це обгрунтовується насамперед низькою ефективністю заходів щодо розведення військ протиборчих сторін (продовжують гинути військовослужбовці та мирні жителі 3 обох сторін конфлікту), високим ризиком розповсюдження зброї на територію України, загрозою дестабілізації внутрішньополітичної обстановки за причини зростання економічної нестабільності та існуючих протиріч у 
суспільстві як щодо шляхів вирішення конфлікту, так і стратегій розвитку держави.

Запровадження миротворчої місії повинно сприяти найшвидшому відновленню інфраструктури територій, які постраждали внаслідок військових дій, здійсненню контролю (заборона ввезення) озброєння та військової техніки в зону конфлікту, підтримання громадського порядку та налагодження зв'язків зі сторонами конфлікту для розв'язання гуманітарних та соціальних проблем, доступу населення до інформаційних ресурсів України. Отже місія має бути розрахована на надання допомоги не тільки у питаннях розведення військ (сил) сторін та припинення вогню, а й на вирішенні суто цивільних питань. Основними компонентами місії мають бути політико-дипломатичний, поліцейський та гуманітарний [11].

Функції миротворчої діяльності на сході України мають бути суттєво розширені - від функцій спостереження та контролю за припиненням вогню до вирішення комплексу складних завдань щодо допомоги в реформуванні економіки і системи управління та інших функцій на припинення розпалювання конфлікту та провокацій серед мирного населення, заборони ввезення озброєння $з$ території РФ, упередження від розгортання i переміщення військ та розширення контрольованих сторонами конфлікту територій, підготовки до проведення виборів. Створення сприятливих економічних, політичних та соціальних умов для повернення внутрішньо перемішених осіб, вільного доступу до інформаційного простору держави можуть бути також завданнями місії. Отже місія ООН на сході України має бути багатопрофільною (багатокомпонентною) та інтегрованою.

Висновки. Підтримка ззовні $\epsilon$ також фактором, що впливає на тривалість та інтенсивність сучасних воєнних конфліктів, як правило, у сторону їх збільшення. До того ж суттєво зменшується ймовірність, що сторони конфлікту можуть дійти згоди шляхом переговорів, що обумовлює необхідність трансформації існуючих підходів до підготовки та проведення сучасних операцій 3 підтримання миру i безпеки, 3 урахуванням наявності прихованої та відкритої підтримки третіми країнами (коаліціями, безпековими організаціями) протиборчих сторін у воєнному конфлікті.

3 огляду на наявність зовнішньої підтримки сторін у конфлікті на сході України актуальним залишається повернення до ініціативи щодо розгортання міжнародної миротворчої місії. Місія має бути розрахована на надання допомоги не тільки у питаннях розведення військ (сил) сторін та припинення вогню, а й на вирішенні суто цивільних питань, тобто бути багатопрофільною (багатокомпонентною) та інтегрованою. Основними компонентами місії доцільним $є$ визначити політико-дипломатичний, поліцейський та гуманітарний.

Постійний моніторинг та аналіз форматів сучасних операцій 3 підтримання миру i безпеки, а особливо їх результатів дасть змогу сконцентрувати увагу воєнно-політичного керівництва держави на перспективних напрямах та форматах співробітництва 3 регіональними та світовими безпековими організаціями в інтересах підтримання миру i безпеки в Україні.

Напрями подалыших досліджень. Полягають у розробленні практичних рекомендацій щодо складу міжнародної багатопрофільної (багатокомпонентної) та інтегрованої місії.

\section{СПИСОК ВИКОРИСТАНОЇ ЛІТЕРАТУРИ}

1. СІПРІ 2018: Щорічник: Озброєння, роззброєння та міжнародна безпека : пер. 3 англ. / Стокгольм. міжнар. ін.-т дослідження миру; Український центр екон. і політ. досліджень ім. О. Разумкова; Редкол. укр. вид. : О. Мельник (керівник проєкту) та ін. Київ : Заповіт, 2018. $504 \mathrm{c}$.

2. Перепелиця Г. М. Конфлікти в посткомуністичній Європі : монографія. Київ : НІСД, 2003. 432 с. (сер. "Воєнна безпека"; вип. 8).

3. Голопатюк Л. С., Розумний О. Д. Аналіз змін стратегії миротворчої діяльності Організації Об'єднаних Націй. аналізу збройного конфлікту на Донбасі. Збірник наукових пращь Центру воєнно-стратегічних досліджень Національного університету оборони Украӥни імені Івана Черняховського. Київ, 2016. № 3(58). C. 48-53.

4. Kouri J. War on Terrorism: Defining "hybrid warfare”. URL: http://canadafreepress.com/ index.php/article/27758 September 16, 2010 (дата звернення 25.04.2020).

5. "Гібридна" війна Росії - виклик і загроза для Європи”. Національна безпека і оборона. Київ, 2016. № 9-10. C. 2-7. URL: http://razumkov.org.ua/uploads/journal/ukr/NSD16 7-168 2016_ukr.pdf (дата звернення 25.04.2020).

6. Власик Ю. Миротворчі операції НАТО, як інструмент підтримання миру та безпеки. КОМА, кореспонденція міжнародної аналітики. 2014. Том 2. № 1. C. 14. 
7. СИПРИ 2015. Ежегодник: Вооружения, разоружение и международная безопасность / пер. с англ. Москва : ИМЭМО РАН, 1998 2015. 2016. 962 c. URL: http://www.imemo.ru (дата звернення 25.04.2020).

8. СІПРІ 2014: Щорічник : Озброєння, роззброєння і міжнародна безпека. Москва : ИМЭМО РАН, 2015. 764 c.

URL: https://www.imemo.ru/index.php?page_id=645\&id $=3038$ (дата звернення 20.04.2020).

9. Іващенко А. М. Еволюція поглядів на стратегію сучасного гібридного конфлікту та сценарії протидії гібридним загрозам. Збірник наукових праць Центру воєнно-стратегічних досліджень Національного університету оборони Украӥни імені Івана Черняховського. Київ, 2015.
№ 1 (53). С. 18-23.

10. Філіпчук В., Октисюк А., Поворозник В., Ярошенко Є. Моделі i ціна врегулювання конфлікту на Донбасі: міжнародний досвід та українські реалії. 2016. С. 11-18. URL: http://icps.com.ua/assets/uploads/images/images/eu /donetsk.pdf (дата звернення 20.04.2020).

11. Голопатюк Л. С., Федянович Д. Л., Шпура М. I. Врегулювання конфлікту на сході України: міжнародний аспект. Украӥнське суспільство в умовах війни: виклики сьогодення та перспективи миротворення : матеріали III Всеукраїнської наук.-практ. конф. (м. Маріуполь, 22 черв. 2020 р.). Маріуполь, 2020.

Стаття надійшла до редакційної колегії 02.06.2020

\section{Analysis of the support provided to warring parties in modern military conflicts and its impact on the ability to conduct peace and security operations}

Annotation
The article highlights the need to take into account the types of support of the warring parties in military conflicts and the transformation of the content of peacekeeping and security operations in the face of the factor of overt and covert support of the parties to the conflict by other states. It has been determined that most conflicts are supported externally in one way or another, and this has a significant impact on the content and possibility of peacekeeping operations. The main categories (types) of support of the parties to the military conflict from the outside are given. It has been investigated that external support is also a factor influencing the duration and intensity of modern military conflicts. It is noted that the military-political leadership of the state chooses an appropriate strategy for resolving the conflict without taking into account the behavior of the other side of the conflict and the nature of the assistance provided to it. Such assistance can be provided simultaneously in many areas of the existing confrontation - political support, economic and financial support, supply of weapons and equipment, training. The experience of conflict resolution in eastern Ukraine has shown that the support provided by the Russian Federation is comprehensive and increases or decreases in areas that correspond to the overall strategy of creating a certain environment of influence on the leadership of Ukraine. The analysis of the Russian hybrid aggression against Ukraine showed that despite the support of the world community for the territorial integrity of the UN, the OSCE is not enough to prevent the conflict in the East from escalating into large-scale armed aggression by Russia. In general, constant monitoring and analysis of the formats of modern peacekeeping and security operations, and especially their results will focus the military-political leadership of the state on promising areas and formats of cooperation with regional and global security organizations in maintaining peace and security in Ukraine.

Keywords: international peacekeeping and security operation; support; modern military conflict. 